\title{
Deglacial intermediate water reorganization: new evidence from the Indian Ocean
}

\author{
S. Romahn ${ }^{1}$, A. Mackensen ${ }^{1}$, J. Groeneveld ${ }^{2}$, and J. Pätzold ${ }^{2}$ \\ ${ }^{1}$ Alfred-Wegener-Institut Helmholtz-Zentrum für Polar- und Meeresforschung, Am Alten Hafen 26, \\ 27568 Bremerhaven, Germany \\ ${ }^{2}$ MARUM - Center for Marine Environmental Sciences, Bremen University, Leobener Straße, 28359 Bremen, Germany \\ Correspondence to: S. Romahn (sarah.romahn@awi.de)
}

Received: 7 June 2013 - Published in Clim. Past Discuss.: 17 July 2013

Revised: 3 January 2014 - Accepted: 7 January 2014 - Published: 10 February 2014

\begin{abstract}
The importance of intermediate water masses in climate change and ocean circulation has been emphasized recently. In particular, Southern Ocean Intermediate Waters (SOIW), such as Antarctic Intermediate Water and Subantarctic Mode Water, are thought to have acted as active interhemispheric transmitter of climate anomalies. Here we reconstruct changes in SOIW signature and spatial and temporal evolution based on a $40 \mathrm{kyr}$ time series of oxygen and carbon isotopes as well as planktic $\mathrm{Mg} / \mathrm{Ca}$ based thermometry from Site GeoB12615-4 in the western Indian Ocean. Our data suggest that SOIW transmitted Antarctic temperature trends to the equatorial Indian Ocean via the "oceanic tunnel" mechanism. Moreover, our results reveal that deglacial SOIW carried a signature of aged Southern Ocean deep water. We find no evidence of increased formation of intermediate waters during the deglaciation.
\end{abstract}

\section{Introduction}

Despite growing evidence that intermediate water masses originating from the Southern Hemisphere are an important component of the global thermohaline circulation, there is disagreement about the variability of chemical properties and the spatial dimension of these water masses through time. Especially the architecture of the Southern Ocean's intermediate level during the last termination is a matter of current debate. For example, an enhanced formation of Antarctic Intermediate Water (AAIW) during Heinrich event 1 (H1) and the Younger Dryas (YD) has been proposed for the Atlantic
(Pahnke et al., 2008), the Pacific (Pahnke and Zahn, 2005) and for the Indian Ocean (Jung et al., 2009).

AAIW is also thought to transmit climate anomalies from the Southern Ocean to the tropics, via the so-called "oceanic tunnel" (Liu and Yang, 2003; Pena et al., 2013). This term describes the flow of southern-sourced waters via an intermediate water level pathway to the low latitude thermocline, where entrainment of this extratropical water has a cooling effect on tropical sea surface temperature (SST). The growing number of high-resolution SST records from shallow depths of tropical oceans, showing an Antarctic-type SST pattern for the last deglaciation (Kiefer et al., 2006; Naidu and Govil, 2010; Mohtadi et al., 2010; Visser et al., 2003; Weldeab et al., 2006), supports this idea and indicates that AAIW is essential for interhemispheric forcing of climate variability.

In this context, the hypothesis that the deglacial atmospheric $\mathrm{CO}_{2}$ increase and $\Delta^{14} \mathrm{C}$ decline could be explained by the release of carbon from an isolated deep water carbon pool (Broecker, 1982) gained new attention. This idea has been corroborated recently since anomalous radiocarbondepleted waters were identified in the Pacific (Marchitto et al., 2007; Sikes et al., 2000; Stott et al., 2009), the Atlantic (Keigwin, 2004; Robinson et al., 2005; Thornalley et al., 2011) and the Indian Ocean (Bryan et al., 2010). These old waters were all detected in thermocline to shallow intermediate depths and interpreted as pulses of AAIW thereby demonstrating the presence of an aged deep water reservoir in the Southern Ocean. Spero and Lea (2002) presented a higher level hypothesis that interprets globally distributed carbon isotope minimum events (CIME, Ziegler et al., 2013) 
at glacial terminations as the result of increased upwelling of aged deep water in the Southern Ocean, once Antarctica began to warm and sea ice melted back. Accordingly, supersaturated deep waters emitted $\mathrm{CO}_{2}$, which resulted in rising $\mathrm{CO}_{2}$ concentrations and decreasing $\delta^{13} \mathrm{C}$ signature of the atmosphere, while the low $\delta^{13} \mathrm{C}$ of these upwelled waters propagated northwards in AAIW and Subantarctic Mode Water (SAMW). The AAIW/SAMW $\delta^{13} \mathrm{C}$ minimum, Antarctic temperature rise and atmospheric $\mathrm{CO}_{2}$ rise coincide because all these effects arise from the same process (Spero and Lea, 2002; Stephens and Keeling, 2000).

High-resolution sediment records from the tropical intermediate ocean are still rare, but they are essential to answer the questions of how the geographical and vertical extent of AAIW changed since the Last Glacial Maximum (LGM), and how AAIW influenced the physical properties of the tropical and subtropical oceans in both hemispheres, and therefore participated in interhemispheric coupling. Here we provide a new high-resolution time series of oxygen and carbon isotopes as well as planktic $\mathrm{Mg} / \mathrm{Ca}$ based SST from the intermediate western Indian Ocean that spans the last $40 \mathrm{kyr}$ to contribute to the current discussion on the importance of AAIW/SAMW as part of the global overturning circulation.

\section{Oceanographic framework}

The study site GeoB12615-4 is located off Tanzania, East Africa, in the western Indian Ocean (Fig. 1). In general, the western Indian Ocean is characterized by considerable monsoon-induced variability of surface ocean circulation. Seasonal reversing winds cause phases of upwelling and downwelling, which affect nutrient availability and surface productivity. Compared to the northern coast of Tanzania, where seasonal upwelling leads to cooler, nutrient-rich waters and higher planktic productivity, surface waters south of $4^{\circ} \mathrm{S}$ (including our study site at $7^{\circ} \mathrm{S}$ ) are stratified yearround. The area is characterized by relatively low surface productivity, coral reef growth and benthic productivity associated with low-nutrient warm waters (Birch et al., 2013; McClanahan, 1988).

The study area receives surface water predominantly from the westward flowing South Equatorial Current (SEC), to a large part supplied by the Indonesian throughflow (Schott et al., 2009). Whereas SAMW from the southeast Indian Ocean is the source for thermocline waters, there are several sources that contribute to the intermediate waters of the Indian Ocean (Fine et al., 2008). High salinity waters formed from Red Sea outflow (Red Sea Water, RSW) spread southwards along the East African continental margin (You, 1998), which can be identified at roughly $600-1400 \mathrm{~m}$ water depth at our study site (Birch et al., 2013, see SOM Fig. S1). As there is evidence that Red Sea outflow was greatly reduced during the LGM (Rohling and Zachariasse, 1996) due to lower sealevel, and that RSW settled deeper in the water column dur-

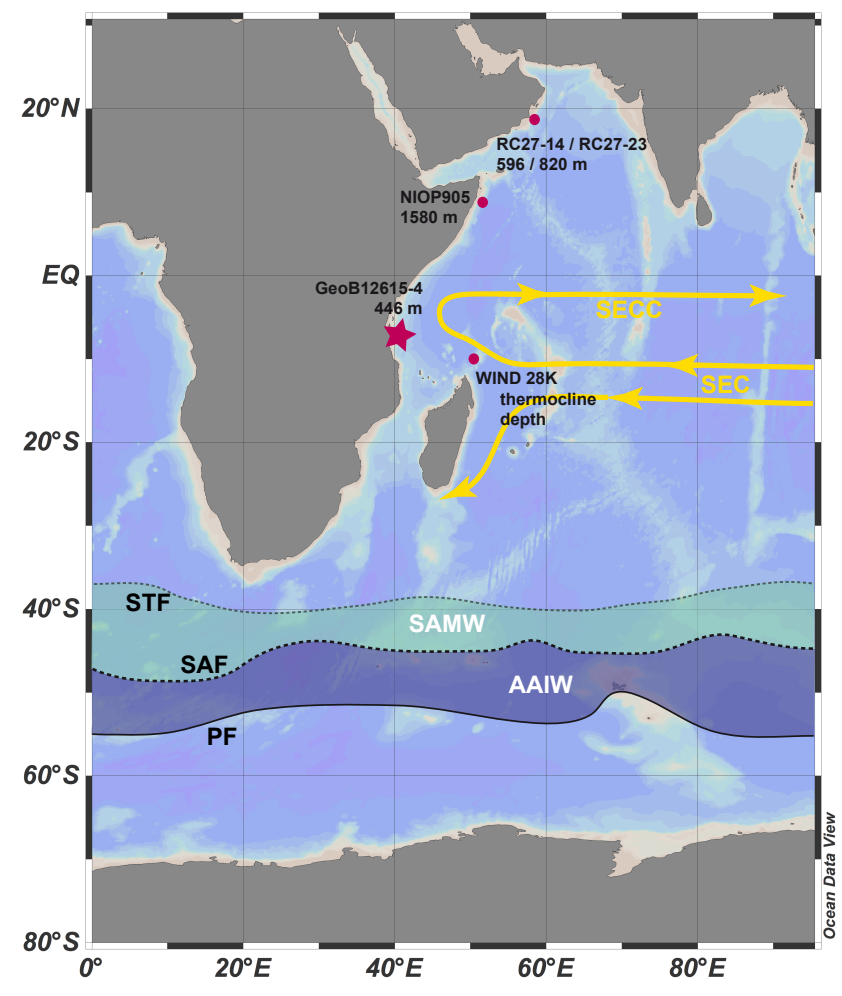

Fig. 1. Location map of sediment core records from the Indian Ocean discussed in this paper. Oman cores RC27-14 and RC2723 (Bryan et al., 2010), Somalia core NIOP905 (Jung et al., 2009), Tanzania core GeoB12615-4 (this study) and Madagascar core WIND28K (Kiefer et al., 2006). Hydrographic fronts and formation area of intermediate water masses: STF: Subtropical Front; SAF: Subantarctic Front; PF: Polar Front; SAMW: Subantarctic Mode Water; AAIW: Antarctic Intermediate Water; SEC and SECC: South Equatorial Current and South Equatorial Countercurrent. Redrawn after Pena et al. (2013) and Schott et al. (2002).

ing the late deglaciation and the early Holocene (Jung et al., 2001), we conclude that RSW did not affect our study site during the last $40 \mathrm{kyr}$.

Although You (1998) estimated the water along the western boundary at $5^{\circ} \mathrm{N}$ to be a mixture of $20 \%$ AAIW, $70 \%$ Red Sea Water, and $10 \%$ Indonesian throughflow, Fine et al. (2008) found AAIW, entering the Indian Ocean from the southwest, to be the most significant ventilation source of the intermediate Indian Ocean, including the Arabian Sea. Both AAIW and SAMW are supposed to be upwelled in the open ocean at $5^{\circ}-10^{\circ} \mathrm{S}$ due to Ekman divergence at the northern edge of the South Equatorial Counter Current (Schott and McCreary, 2001).

The formation of both AAIW and SAMW in the modern ocean is associated with sinking at the Subantarctic Front (SAF) at $45^{\circ}$ to $55^{\circ} \mathrm{S}$ (Hartin et al., 2011; McCartney, 1977; Sloyan and Rintoul, 2001). In the past years, it has become common practice in palaeoceanographic studies to refer to AAIW/SAMW as a single entity when speaking 
of, in general, a glacial southern component intermediate water, which originates from circumantarctic surface waters, subducts and subsequently spreads northwards (Bryan et al., 2010; Chen et al., 2011; Ninnemann and Charles, 1997; Spero and Lea, 2002). Although this is a simplification, it seems helpful when hypothesizing (schematically) about changes in Southern Ocean overturning (Marshall and Speer, 2012; Skinner et al., 2010). For the sake of clarity, we refer to "Southern Ocean Intermediate Water" (SOIW) (Pena et al., 2013) subsequently in the text, always keeping in mind that this term represents southern component intermediate water as part of the Southern Ocean overturning circulation.

\section{Material and methods}

\subsection{Sampling}

The gravity core GeoB12615-4 was recovered during Meteor cruise M75/2 in February 2008 at $7^{\circ} 08.30^{\prime} \mathrm{S}, 39^{\circ} 50.45^{\prime} \mathrm{W}$ from $446 \mathrm{~m}$ water depth and is $644 \mathrm{~cm}$ long (Savoye et al., 2013). For this study we sampled at $4 \mathrm{~cm}$ spacing with a sample width of $1 \mathrm{~cm}$. The sediments were wet sieved over $63 \mu \mathrm{m}, 125 \mu \mathrm{m}$ and $2 \mathrm{~mm}$ and dried at $40^{\circ} \mathrm{C}$.

\subsection{Age model}

The chronology is based on 16 AMS (accelerator mass spectrometer) radiocarbon analyses, carried out at the Leibniz Laboratory for Radiometric Dating and Isotope Research, Kiel. Equal percentages of mixed-layer-dwelling planktic foraminifera species (Globigerinoides ruber, Globigerinoides sacculifer, Globigerinella aequilateralis, Globigerinoides conglobatus), which live between 50 and $100 \mathrm{~m}$ water depth (Hutson, 1977; Bé and Hutson, 1977; Birch et al., 2013), were used for each analysis (see SOM Table S1). Measured radiocarbon ages were converted into calibrated ages before present (BP) using the Calib 6.0 software (Stuiver et al., 2005), based on the Marine09 calibration curve and a reservoir age correction of $\Delta \mathrm{R}=140 \mathrm{yr}$ (Southon et al., 2002). The sedimentation rate varies strongly between the Holocene (average of $46 \mathrm{~cm} \mathrm{kyr}^{-1}$, highest beween $\sim 8.7$ and $8.2 \mathrm{kyr}$ with $70 \mathrm{~cm} \mathrm{kyr}^{-1}$ ) and the last glacial period (below $10 \mathrm{cmkyr}^{-1}$, see SOM, Fig. S2). The complete data set covers the past $\sim 40 \mathrm{kyr}$ (Fig. 2 ).

\subsection{Oxygen and carbon isotopes}

For isotopic analysis, six to eight individuals of Globigerinoides ruber white s.s., as the shallowest living species at the study site (Birch et al., 2013; Fallet et al., 2010), were selected from the $250-300 \mu \mathrm{m}$ fraction. Duplicate measurements were carried out of the deglacial core section (444$500 \mathrm{~cm}$, see SOM, Fig. S3). Three to four individuals of benthic foraminifer Planulina ariminensis were selected from the total fraction for analysis. Isotope measurements were

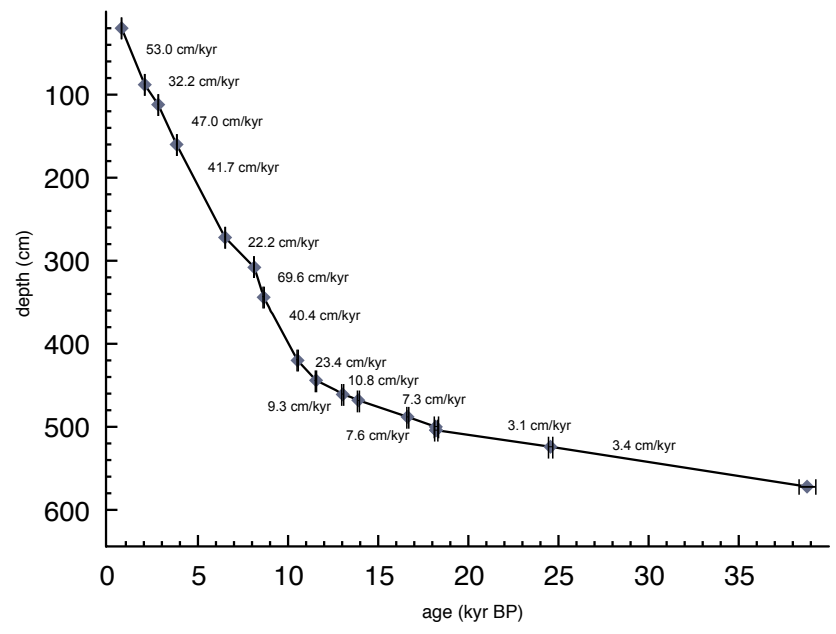

Fig. 2. Age-depth relationship of core GeoB12615-4, including linear sedimentation rates and calibrated radiocarbon ages with error bars.

performed using Finnigan MAT 251 and MAT 253 isotope ratio mass spectrometers coupled to automatic carbonate preparation devices Kiel II and Kiel IV, respectively. The isotope measurements were calibrated via the NBS 19 international standard to the PDB scale. All results are given in $\delta$ notation versus VPDB. Precision of measurements based on an internal laboratory standard (Solnhofen limestone) measured over a one-year period together with samples was better than $\pm 0.08 \%$ and $\pm 0.06 \%$ o for oxygen and carbon isotopes, respectively.

\section{$3.4 \mathrm{Mg} / \mathrm{Ca}$ ratios}

A total of 35 to 45 individuals of $G$. ruber white, s.s. (250$300 \mu \mathrm{m}$ ), were selected for $\mathrm{Mg} / \mathrm{Ca}$ ratio analysis of every second sample of the uppermost part of the core, resulting in a sampling interval of $8 \mathrm{~cm}$. In contrast, in the lowermost $2.50 \mathrm{~m}$ of the core each sample was analysed $(4 \mathrm{~cm}$ sampling interval). The tests were gently crushed and cleaned according to the cleaning protocol of Barker et al. (2003). The dissolved samples were centrifuged $(10 \mathrm{~min}$ at $6000 \mathrm{rpm}$; revolutions per minute), transferred into autosampler tubes and diluted for analysis. $\mathrm{Mg} / \mathrm{Ca}$ ratios were measured using an Inductively Coupled Plasma Optical Emission Spectrophotometer (ICP-OES) (Agilent Technologies, 700 Series with autosampler (ASX-520 Cetac) and micronebulizer) housed at the MARUM - Center for Marine Environmental Sciences, University of Bremen. The $\mathrm{Mg} / \mathrm{Ca}$ values are reported as $\mathrm{mmol} \mathrm{mol}^{-1}$. Instrumental precision was determined by analysis of an external, in-house standard $\left(\mathrm{Mg} / \mathrm{Ca}=2.93 \mathrm{mmol} \mathrm{mol}^{-1}\right)$, which was measured after every fifth sample. The standard deviation of the external standard was $\pm 0.48 \%$. Reproducibility of the samples $(n=14)$ was $\pm 0.09 \mathrm{mmol} \mathrm{mol}^{-1}$. Long-term measurement of an international limestone standard (ECRM752-1; Greaves et al., 
2008) allows for interlaboratory comparison. $\mathrm{Mn} / \mathrm{Ca}, \mathrm{Fe} / \mathrm{Ca}$ and $\mathrm{Al} / \mathrm{Ca}$ ratios were determined along with $\mathrm{Mg} / \mathrm{Ca}$ because clay contamination of the foraminifera tests can affect the $\mathrm{Mg} / \mathrm{Ca}$ ratios resulting in overestimated SST (Barker et al., 2003). Our results indicate no significant Mg contributions due to manganese oxides, manganese-rich carbonates or clay contamination because average $\mathrm{Mn} / \mathrm{Ca}, \mathrm{Fe} / \mathrm{Ca}$ and $\mathrm{Al} / \mathrm{Ca}$ ratios were $<0.1 \mathrm{mmol} \mathrm{mol}^{-1}$. SST $\left({ }^{\circ} \mathrm{C}\right)$ was calculated using the species-specific equation given by Anand et al. (2003):

$\mathrm{Mg} / \mathrm{Ca}\left(\mathrm{mmol} \mathrm{mol}^{-1}\right)=0.38 \exp (0.090 T)$

with a standard deviation of $\pm 1.1-1.4^{\circ} \mathrm{C}$ (Dekens et al., 2002; Anand et al., 2003).

Although G. ruber calcifies during the warmest month, recent studies revealed $G$. ruber reflects mean annual SST reliably due to natural averaging processes and is therefore most suitable for SST reconstructions in this region (Birch et al., 2013; Fallet et al., 2010). The modern average SST close to our study site is $27.3^{\circ} \mathrm{C}$ with an annual range of approximately $4^{\circ} \mathrm{C}\left(25^{\circ}-29^{\circ} \mathrm{C}\right)$ (Damassa et al., 2006). Derived temperatures of the uppermost core samples (see SOM, Table S2) are at the upper end of the annual range, which suggest our SST might represent a more seasonal signal due to seasonal variation of shell fluxes (Fallet et al., 2012). Alternatively, the given modern annual SST might be undervalued, since SSTs closer to the East African coast tend to be up to $\sim 2{ }^{\circ} \mathrm{C}$ warmer than offshore (Fallet et al., 2012) and our SST reconstruction reflects the warmer coastal annual SST.

\section{Results}

The $\delta^{18} \mathrm{O}$ record of planktic G. ruber white s.s. (noted as $\delta^{18} \mathrm{O}_{\mathrm{p}}$ ) shifts between $-0.25 \%$ o during glacial conditions and $-2.2 \%$ during the Holocene (Fig. 3b). The deglacial decline of $\delta^{18} \mathrm{O}_{\mathrm{p}}$ starts at $18.2 \mathrm{kyr}$ and shows a clear setback to higher values at $13 \mathrm{kyr}$, which appears to resemble the Greenland ice cores and therefore Northern Hemisphere climate variability. In contrast, the stable isotope records of benthic $P$. ariminensis (noted as $\delta^{18} \mathrm{O}_{\mathrm{b}}$ and $\delta^{13} \mathrm{C}_{\mathrm{b}}$ ) and the SST record are out of phase with surface oxygen isotopes and resemble Antarctic climate variability. The $\delta^{18} \mathrm{O}_{\mathrm{b}}$ (Fig. 3f) shifts between $2.5 \%$ in the LGM and $\sim 1 \%$ for the Holocene. The record exhibits a deglacial decline starting at $19.5 \mathrm{kyr}$, and a slackening of $\delta^{18} \mathrm{O}_{\mathrm{b}}$ decrease during the Antarctic Cold Reversal (ACR). The record of surface carbon isotopes (Fig. 3c) shows quite consistent values of $0.9-1.1 \%$ o during the glacial and an abrupt increase of $0.7 \%$ during the early Holocene to $\sim 1.4 \%$ o. The $\delta^{13} \mathrm{C}_{\mathrm{b}}$ varies around $1.5 \%$ o between 35 and $18.2 \mathrm{kyr}$ (Fig. 3e). Values decrease rapidly at $18.2 \mathrm{kyr}$ (about $0.4 \%$ ), increase slightly (about $0.1 \%$ ) during the ACR and reach a minimum of $0.9 \%$ in the early Holocene. Starting at $10 \mathrm{kyr}, \delta^{13} \mathrm{C}_{\mathrm{b}}$ gradually increases (about $0.5 \%$ ) to Holocene levels of approximately $1.5 \%$. The $\mathrm{Mg} / \mathrm{Ca}$ based

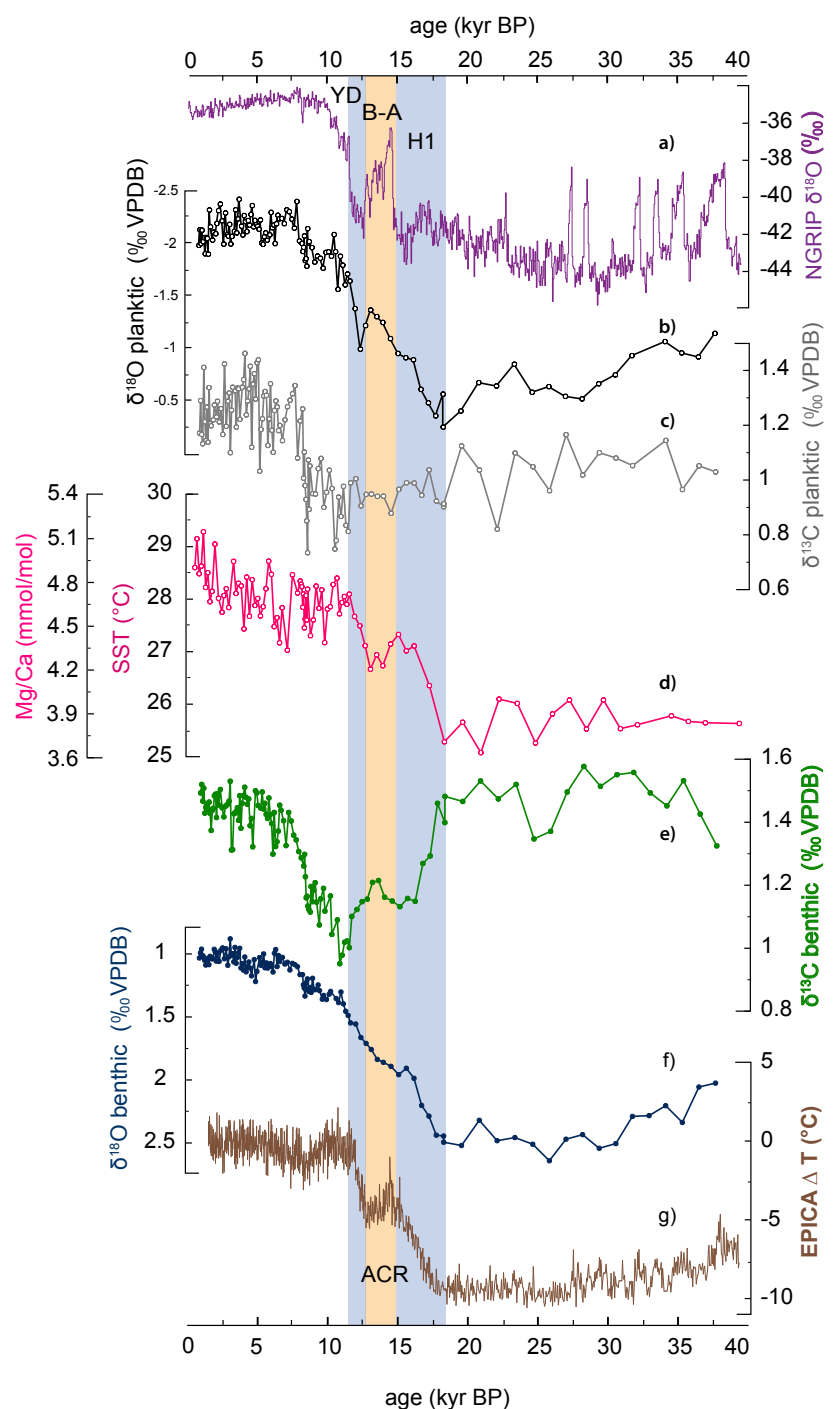

Fig. 3. Comparison of ice core records with data of GeoB12615-4 spanning the last $40 \mathrm{kyr}$. (a) NGRIP stable oxygen isotopic record (Andersen et al., 2004). (b) $\delta^{18} \mathrm{O}_{\text {planktic record of GeoB12615-4 }}$

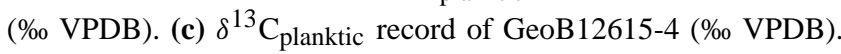
(d) Shell $\mathrm{Mg} / \mathrm{Ca}$ ratio of planktic foraminifera $\left(\mathrm{mmol} \mathrm{mol}^{-1}\right)$ and reconstructed SST record of GeoB12615-4 ( $\left.{ }^{\circ} \mathrm{C}\right)$. (e) $\delta^{13} \mathrm{C}_{\text {benthic }}$ record of GeoB12615-4 (\%o VPDB). (f) $\delta^{18} \mathrm{O}_{\text {benthic }}$ record of GeoB12615-4 (\%o VPDB). (g) EPICA Dome C ice core temperature estimates (Jouzel et al., 2007).

SST record (Fig. 3d) exhibits a deglacial variability similar to $\delta^{13} \mathrm{C}_{\mathrm{b}}$. The record shows a sudden temperature increase from $\sim 25^{\circ}$ to $27^{\circ} \mathrm{C}$ at $18.2 \mathrm{kyr}$, an ACR-like temperature drop starting at $15 \mathrm{kyr}$, and a final increase to Holocene temperatures $\left(28^{\circ}-29^{\circ} \mathrm{C}\right)$ at around $13 \mathrm{kyr}$. To summarize, the $\delta^{18} \mathrm{O}_{\mathrm{p}}$ surface signal can be linked to Northern Hemisphere (NH) climate variability, whereas both $\mathrm{Mg} / \mathrm{Ca}$ based SST and benthic $\delta^{18} \mathrm{O}_{\mathrm{b}}$, as well as the timing of $\delta^{13} \mathrm{C}_{\mathrm{b}}$ variability can be linked to Antarctic climate records. 


\section{Discussion}

\subsection{Oceanic tunnel transmitting Antarctic temperature}

It is a widespread feature of the Indian Ocean to show an Antarctic-style deglacial warming in surface temperature records (Govil and Naidu, 2010; Huguet et al., 2006; Levi et al., 2007; Mohtadi et al., 2010), while surface $\delta^{18} \mathrm{O}$ varies independently of SST reconstructions and likely reflects the influence of the monsoon (Anand et al., 2008; Huguet et al., 2006; Levi et al., 2007). On the contrary, benthic $\delta^{18} \mathrm{O}$ records of intermediate depth carry a typical Antarctic signature (Anand et al., 2008; Jung et al., 2009; Lueckge et al., 2012). The idea that SST variability in the equatorial western Indian Ocean is controlled by Antarctic temperature via SAMW has been proposed by Kiefer et al. (2006) and was corroborated by Naidu and Govil (2010). The authors suggest the "oceanic tunnel" mechanism (Liu and Yang, 2003), in form of SAMW that originates from subantarctic surface waters. After subducting and spreading northwards, SAMW returns to the surface in regions of equatorial upwelling and thus conveys surface water anomalies from the Subantarctic Zone to the tropical Indian Ocean. Here we confirm this interpretation by presenting a SST record from a location of modern SOIW influence that clearly shows simultaneous warming of the tropical western Indian Ocean and Antarctica (Fig. 3). We find that our data necessarily call for an oceanic mechanism that modulated SST variability, for two reasons.

First, we can exclude that atmospheric processes controlled SST variability, because $\delta^{18} \mathrm{O}_{\mathrm{p}}$ of GeoB126154 with its distinct $\mathrm{NH}$ pattern differs so clearly from the SST data. This indicates two independent factors affect the surface water properties at our study site. Similarly, the Arabian Sea record from NIOP905 (Huguet et al., 2006) exhibits an Antarctic-style SST pattern as well, evident in two independent surface temperature proxy reconstructions (TEX $_{86}$ and alkenones), while the corresponding $\delta^{15} \mathrm{~N}$ record and planktic $\delta^{18} \mathrm{O}$ follows NH climate variability. The $\delta^{15} \mathrm{~N}$, a proxy for productivity changes, as well as planktic $\delta^{18} \mathrm{O}$ likely reflect the strength of the Arabian Sea summer monsoon (Ivanochko et al., 2005). If we conclude that our $\delta^{18} \mathrm{O}_{\mathrm{p}}$ reflects monsoon strength as well and hence is controlled by an atmospheric process following $\mathrm{NH}$ climate, then SST variability following Antarctic climate must be modulated differently. If atmospheric control can be ruled out, only oceanic control remains as a mechanism influencing SST.

Second, the benthic record of GeoB12615-4 does not only exhibit a $\delta^{18} \mathrm{O}_{\mathrm{b}}$ signal that is in phase with Antarctic temperature variability, but also shows a distinct carbon isotope minimum event (CIME) during the deglaciation (Ninnemann and Charles, 1997; Spero and Lea, 2002). This minimum is a common feature of

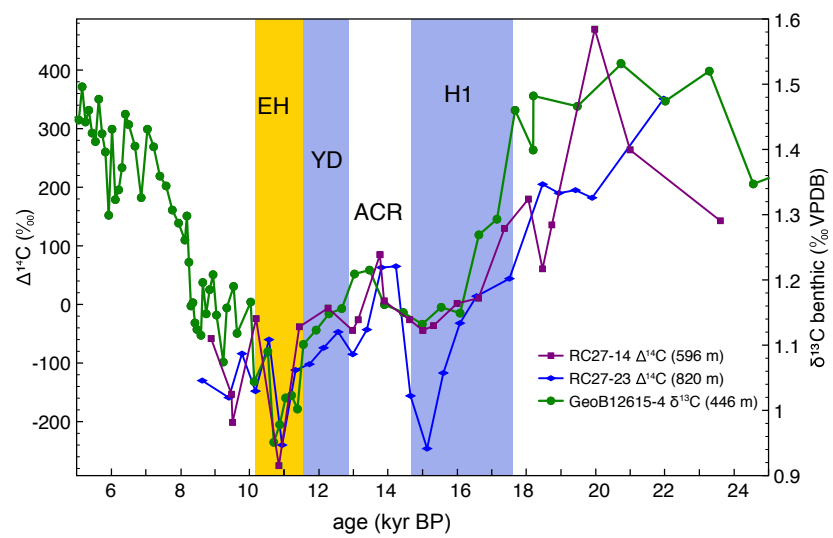

Fig. 4. Comparison of GeoB12615-4 and sediment records from the Arabian Sea. GeoB12615-4: $\delta^{13} C_{\text {benthic }}$ record (\%o VPDB; green). Arabian Sea RC27-14 and RC27-23 (Bryan et al., 2010): intermediate water $\Delta^{14} \mathrm{C}$ as a measure for ventilation age.

both southern high latitude planktic $\delta^{13} \mathrm{C}$ profiles (Bostock et al., 2004; Lopes dos Santos et al., 2012; Ninnemann and Charles, 1997; Pahnke and Zahn, 2005) and of tropical $\delta^{13} \mathrm{C}$ records of subthermocline and intermediate depth (Curry and Oppo, 2005; Oppo and Fairbanks, 1989; Stott et al., 2009; Zahn and Stüber, 2002). Oppo and Fairbanks (1989) suggested CIMEs to be linked to SOIW, and Lynch-Stieglitz et al. (1994) and Ninnemann and Charles (1997) assumed that CIMEs at sites ventilated by SOIW reflect a preformed signal from subantarctic surface waters. The combination of Antarctic-style benthic $\delta^{18} \mathrm{O}$ and benthic $\delta^{13} \mathrm{C}$ from site GeoB12615-4, showing a distinct deglacial minimum, confirms that the "oceanic tunnel" in form of SOIW is the most likely mechanism controlling past SST in the western Indian Ocean.

\subsection{SOIW formation during the deglaciation}

If SST variability is controlled by SOIW, transmitting Antarctic temperature to the tropics, what in turn does the benthic $\delta^{13} \mathrm{C}$ record tell us about SOIW variability since glacial times? We first evaluate how the observed pattern in our benthic signal can be best explained by current concepts of deglacial $\delta^{13} \mathrm{C}_{\text {DIC }}$ setting in the Southern Ocean.

We then discuss how the spatial extent of SOIW may have varied since the last glacial by combining our findings in the western Indian Ocean with recent data that also focus on SOIW variability.

\subsubsection{Preformed $\delta^{13} \mathrm{C}$ of deglacial SOIW?}

As described above, the globally distributed deglacial $\delta^{13} \mathrm{C}$ minima (CIME) are consistently interpreted as reflecting deep upwelling in the Southern Ocean and intermediate distribution of old, $\delta^{13} \mathrm{C}$ depleted water (Spero and Lea, 2002). 
Moreover, findings of radiocarbon depleted intermediate waters during the deglacial have been reported from all oceans so far (Bryan et al., 2010; Mangini et al., 2010; Marchitto et al., 2007; Stott et al., 2009; Thornalley et al., 2011), but there are just as many results where no old water could be found at intermediate water depths (Cléroux et al., 2011; De Pol-Holz et al., 2010, 2012; Rose et al., 2010; Sortor and Lund, 2011). If the strong depletion in radiocarbon was the result of increased upwelling of a long-isolated carbon reservoir, it should exactly coincide with a $\delta^{13} \mathrm{C}$ minimum of the same water mass, just as described by Spero and Lea (2002). This is the case for sites with pronounced radiocarbon depletions, such as off Baja California (Marchitto et al., 2007) and south of Iceland (Thornalley et al., 2010). This hypothesis also holds for the Indian Ocean, if we combine the results of Geob12615-4 and recently published ventilation age reconstructions in the Arabian Sea: we compare $\delta^{13} \mathrm{C}_{\mathrm{b}}$ of GeoB12615-4 to intermediate water ventilation $\left({ }^{14} \mathrm{C}(\% \circ)\right)$, reconstructed from sediment cores RC27-14 and RC27-23 (Bryan et al., 2010), and see a remarkable similarity between the minima in our benthic carbon and highest values of intermediate water $\Delta^{14} \mathrm{C}$, especially when comparing to RC2714 (596 m water depth) (Fig. 4). Whereas other ${ }^{14} \mathrm{C}$ anomalies that are likely transmitted by SOIW, indicate pulses of aged intermediate water during $\mathrm{H} 1$ and the Younger Dryas (Marchitto et al., 2007), the Arabian Sea records do not show high ventilation ages during YD. Instead, we see very large benthos-plankton age differences and therefore the highest ventilation ages during the early Holocene in the Arabian Sea. This is exactly the same time interval as when the lowest $\delta^{13} \mathrm{C}_{\mathrm{b}}$ values are found in GeoB12615-4. Additionally, the signals of core RC27-14 (596 m) and GeoB12615-4 (446 m), both monitoring a similar water depth, correlate more explicitly, which argues for a large-scale connection and a water mass such as SOIW to be the transmitter of both anomalies in the Indian Ocean. Therefore, we conclude that the bottom water signal of GeoB12615-4 reflects the deglacial evolution of the Southern Ocean and provides evidence of upwelled, aged deep waters (Broecker, 1982) at high southern latitudes, which then flowed northwards into all the ocean basins as SOIW.

\subsubsection{CIME caused by temperature-dependent fractionation?}

The carbon isotopic fractionation between atmosphere and ocean increases with decreasing temperature, with lower temperatures resulting in more enriched $\delta^{13} \mathrm{C}$ values of dissolved inorganic carbon $\left(\delta^{13} \mathrm{C}_{\text {DIC }}\right)$ in seawater (Broecker and Maier-Reimer, 1992; Mackensen, 2008). Though there is no region where surface ocean carbon is in complete isotopic equilibrium with the atmosphere, the effects related to airsea gas exchange play an important role in defining the surface $\delta^{13} \mathrm{C}_{\text {DIC }}$, working in the opposite direction to the effect of biological cycling (Broecker and Maier-Reimer, 1992;

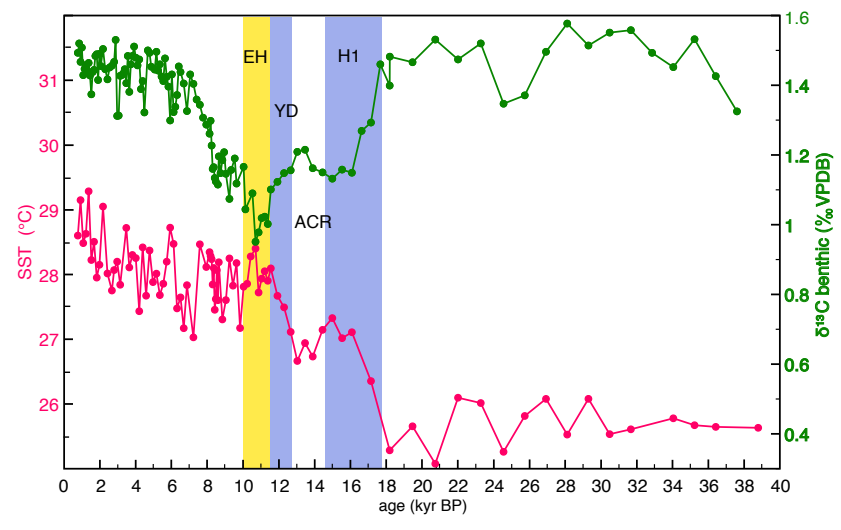

Fig. 5. Comparison of $\delta^{13} \mathrm{C}_{\text {benthic }}$ record in \%o VPDB (green) and SST record based on shell $\mathrm{Mg} / \mathrm{Ca}$ ratios of planktic foraminifera $\left({ }^{\circ} \mathrm{C}\right.$; pink) of GeoB12615-4. EH, YD, ACR and H1 indicate early Holocene, Younger Dryas, Antarctic Cold Reversal and Heinrich event 1 , respectively.

Lynch-Stieglitz et al., 1995; Mackensen, 2012). Today, we find the highest $\delta^{13} \mathrm{C}_{\mathrm{DIC}}$ values of surface waters along the $\mathrm{SAF}$, between $45^{\circ}$ and $55^{\circ} \mathrm{S}$, because of low circumantarctic temperatures and enhanced air-sea gas exchange (Broecker and Maier-Reimer, 1992).

As the SST record and $\delta^{13} \mathrm{C}_{\mathrm{b}}$ (reflecting SOIW) of GeoB12615-4 match so well during the deglaciation (Fig. 5), one could suggest that $\delta^{13} \mathrm{C}_{\mathrm{b}}$ and therefore $\delta^{13} \mathrm{C}_{\mathrm{DIC}}$ of SOIW was simply the expression of temperature change at high southern latitudes, or, in other words, the formation area of SOIW: during the LGM, $\delta^{13} \mathrm{C}_{\text {DIC }}$ of sea-ice-free surface seawater along the SAF was high due to low temperatures and high wind speed. A deglacial temperature rise may have decreased the thermodynamic fractionation and therefore led to lower values of surface $\delta^{13} \mathrm{C}_{\text {DIC }}$, always tracing centennialscale Antarctic temperature variability. This signal was transferred to low latitudes as SOIW almost simultaneously. In fact, if we assume $0.1 \%$ o depletion of $\delta^{13} \mathrm{C}_{\text {DIC }}$ per degree centigrade of cooling (Mook et al., 1974; Zhang et al., 1995), we would expect a $\delta^{13} \mathrm{C}$ decrease of $0.35 \%$ or the deglaciation until the early Holocene, and this comes close to the observed $\sim 0.5 \%$ o shift in deglacial $\delta^{13} \mathrm{C}_{\mathrm{b}}$. Additionally, a displacement of the westerly wind belt (Lamy et al., 2004; Wyrwoll et al., 2000) may have reduced air-sea gas exchange of Southern Ocean surface waters, as proposed by Ninnemann and Charles (1997). According to this interpretation, deglacial $\delta^{13} \mathrm{C}_{\mathrm{b}}$ of GeoB12615-4 as well as the global occurrence of CIME at shallow depths can be entirely explained by Southern Ocean surface water temperature variability and accordingly altered thermodynamic fractionation during airsea $\mathrm{CO}_{2}$ exchange at high latitudes, as originally proposed by Ninnemann and Charles (1997). Indeed, based on our data alone we could reason that the deglacial CIME in our record is a purely temperature-dependent signal. 


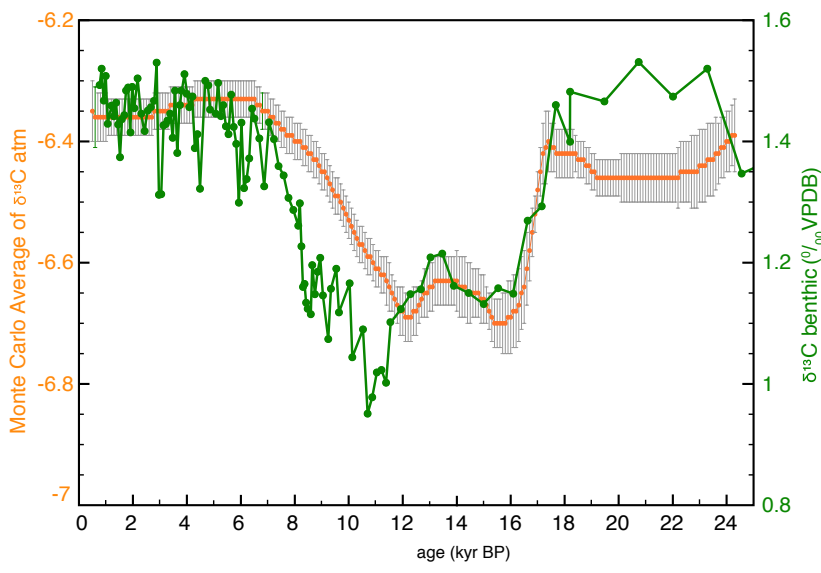

Fig. 6. Comparison of the benthic carbon isotope record of GeoB12615-4 (\%o VPDB; green) and ice core reconstructions of atmospheric $\delta^{13} \mathrm{C}\left(\delta^{13} \mathrm{C}_{\mathrm{atm}}\right)$ for the last $24 \mathrm{kyr}$ (yellow, Schmitt et al., 2012).

However, the corresponding radiocarbon depletions off Oman (Bryan et al., 2010) call for a mechanism that best explains the occurrence of both signals, i.e. CIME and radiocarbon depletions, detected in the same water mass; namely the mechanism proposed by Spero and Lea (2002). Nevertheless, since we cannot determine important prerequisites, such as the degree of equilibration between the surface ocean carbon and atmosphere, we cannot completely exclude a role for temperature-dependent fractionation during air-sea gas exchange in production of the deglacial CIME in SOIW.

\subsubsection{An additional atmospheric pathway for transmission of CIME?}

The carbon isotope ratio of atmospheric $\mathrm{CO}_{2}\left(\delta^{13} \mathrm{C}_{\mathrm{atm}}\right)$ experienced pronounced depletion during the deglaciation as well. New findings of $\delta^{13} C_{\text {atm }}$ (Schmitt et al., 2012) are likewise explained by the release of old carbon from the deep ocean, and are in line with the concept of deep-water outgassing proposed by Spero and Lea (2002). The atmospheric record shows $\delta^{13} \mathrm{C}$ minima during $\mathrm{H} 1$ and $\mathrm{YD}$, which is in line with the timing of CIME synchronous with early $\mathrm{H} 1$ in many marine records, and also correlates with our benthic carbon isotope record (Fig. 6). Since a pronounced CIME without associated radiocarbon depletion has been identified in intermediate waters off equatorial Africa (Cléroux et al., 2011), one has to consider that both signals need not necessarily be coupled, even though they may arise from the same process. In the Philippine Sea, western Pacific, the carbon isotope minimum is recorded in both surface and subsurface water, but with differing amplitude and timing. The independent signals are thought to be formed by atmospheric $\mathrm{CO}_{2}$ imprint on the surface water in case of the surface signal, and by AAIW via the "oceanic tunnel" in case of that in the subsurface (Chen et al., 2011). So, the

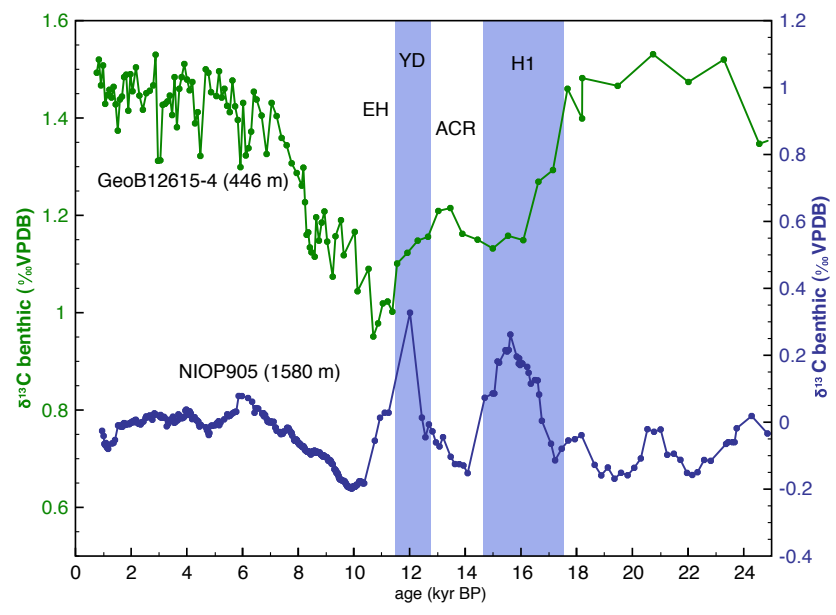

Fig. 7. Comparison of benthic carbon isotope records. GeoB126154 (green) and NIOP905 (purple). For core position see Fig. 1.

atmosphere can probably work as an additional pathway transmitting the deglacial CIME to tropical oceans, which should be considered when interpreting deglacial $\delta^{13} \mathrm{C}$ profiles. Comparing our data (Fig. 6) to the $\delta^{13} \mathrm{C}_{\mathrm{atm}}$ record of Schmitt et al. (2012), the initial drop in both $\delta^{13} C_{a t m}$ and $\delta^{13} \mathrm{C}$ of SOIW occurs synchronously, and is of the same magnitude (approximately $0.3 \%$ ). However, since $12.3 \mathrm{kyr}$ BP both records vary independently. This mismatch, along with the synchronous peaks of old carbon off Oman (Bryan et al., 2010), confirms that the "oceanic tunnel" (Liu and Yang, 2003) mechanism is configuring the intermediate water history at our site.

\subsubsection{Enhanced glacial SOIW formation?}

A current hypothesis proposes an enhanced northward extension of AAIW during H1 and YD to the Arabian Sea (Jung et al., 2009). The benthic $\delta^{13} \mathrm{C}$ record of sediment core NIOP905 $(1580 \mathrm{~m})$ from the continental slope off Somalia (Fig. 7, see Fig. 1 for core location) shows higher $\delta^{13} \mathrm{C}$ values during $\mathrm{H} 1$ and $\mathrm{YD}$, which is suggested to reflect intensified AAIW formation and inflow to the Indian Ocean (Jung et al., 2009). Although NIOP905 is located close to our study site, we cannot confirm this suggestion, since our record does not show higher deglacial $\delta^{13} \mathrm{C}$, compared to Holocene or glacial values. Instead, the $\delta^{13} \mathrm{C}$ data sets of NIOP905 and GeoB12615-4 are anticorrelated during the specific time interval of $\mathrm{H} 1$ and YD (Fig. 7). This means that when both hypotheses on deglacial SOIW variability in the western Indian Ocean are based on $\delta^{13} \mathrm{C}$ alone, they conflict with each other. Providing that deglacial SOIW formed as proposed by Spero and Lea (2002), carrying a pronounced $\delta^{13} \mathrm{C}$ minimum as a large-scale water mass signal, we suggest NIOP905 might not record SOIW at any time. Instead, it seems to record a water mass that is unaffected by the specific upwelling processes in the deglacial Southern Ocean, 
that led to both CIME and strong radiocarbon depletions in SOIW. It rather resembles the $\delta^{13} \mathrm{C}_{\mathrm{b}}$ pattern observed in the mid-depth South Atlantic (Ziegler et al., 2013), representing one part of the "mid-depth overturning circuit" in the Southern Ocean. Particularly higher $\delta^{13} \mathrm{C}$ values of deglacial Circumpolar Deep Water (CDW) might result from changing endmember compositions in the deep Southern Ocean (Curry and Oppo, 2005). Hence, we suggest that the benthic record of NIOP905 predominantly represents a deglacial analogue of modern CDW, as part of the Southern Ocean overturning (Skinner et al., 2010; Ziegler et al., 2013). However, unless both interpretations in the western Indian Ocean are solely based on $\delta^{13} \mathrm{C}$ and not supported or challenged by additional proxy data sets, our consideration is preliminary. Clearly, more data from intermediate depths are needed to constrain hypotheses on SOIW variability in the past.

\section{Conclusions}

In this study we present evidence that deglacial SST variability in the western Indian Ocean is primarily controlled by Antarctic air temperature, which was transmitted to the equatorial Indian Ocean on a subsurface pathway by SOIW. We discuss current concepts of what determines the deglacial SOIW $\delta^{13} \mathrm{C}$ signature, and we support the hypothesis (Spero and Lea, 2002) that deglacial upwelling of aged deep water in the Southern Ocean caused a drop in atmospheric, surface and subsurface ocean carbon isotopy (CIME) and thereby determines the SOIW signature recorded at our study site.

Moreover, we discuss how our findings fit into the concept of enhanced SOIW inflow during the deglacial, and we cannot confirm increased extension of deglacial SOIW to the western Indian Ocean. We point out that hypotheses on SOIW variability in the past need to be constrained and, probably, expanded by additional data. Finally, it is not clear why regional (Marchitto et al., 2007) and global $\delta^{13} \mathrm{C}$ records (Schmitt et al., 2012) consistently show a CIME during YD, while Indian Ocean SOIW exhibit a pronounced CIME and corresponding high ventilation ages (Bryan et al., 2010) during the early Holocene.

\section{Supplementary material related to this article is available online at http://www.clim-past.net/10/293/2014/ cp-10-293-2014-supplement.pdf.}

Acknowledgements. We thank Günther Meyer, Silvana Pape, Heike Röben, Lisa Schönborn and Susanne Wiebe for help and advice in the laboratories, as well as the ship crew and scientific parties of RV Meteor cruise M75/2. We also thank Franziska Kersten and Johannes Ullermann for essential discussion and helpful comments. We are grateful to Thorsten Kiefer and two anonymous reviewers for their constructive criticism that substantially improved the paper. This work was funded by the Deutsche Forschungsgemeinschaft (DFG) as part of the DFG-Research Center/Cluster of Excellence "The Ocean in the Earth System".

Edited by: T. Kiefer

\section{References}

Anand, P., Elderfield, H., and Conte, M. H.: Calibration of $\mathrm{Mg} / \mathrm{Ca}$ thermometry in planktonic foraminifera from a sediment trap time series, Paleoceanography, 18, PA1050, doi:10.1029/2002PA000846, 2003.

Anand, P., Kroon, D., Singh, A. D., Ganeshram, R. S., Ganssen, G., and Elderfield, H.: Coupled sea surface temperatureseawater $\delta^{18} \mathrm{O}$ reconstructions in the Arabian Sea at the millennial scale for the last $35 \mathrm{ka}$, Paleoceanography, 23, PA4207, doi:10.1029/2007PA001564, 2008.

Andersen, K. K., Azuma, N., Barnola, J.-M., Bigler, M., Biscaye, P., Caillon, N., Chappellaz, J., Clausen, H. B., Dahl-Jensen, D., and Fischer, H.: High-resolution record of Northern Hemisphere climate extending into the last interglacial period, Nature, 431, 147-151, 2004.

Barker, S., Greaves, M., and Elderfield, H.: A study of cleaning procedures used for foraminiferal $\mathrm{Mg} / \mathrm{Ca}$ paleothermometry, Geochem. Geophys. Geosyst, 4, 8407, doi:10.1029/2003GC000559, 2003.

Bé, A. W. H. and Hutson, W.: Ecology of planctonic foraminifera and biogeographic patterns of life and fossil assemblages in the Indian Ocean, Micropaleontology, 22, 369-414, 1977.

Birch, H., Coxall, H. K., Pearson, P. N., Kroon, D., and O’Regan, M.: Planktonic foraminifera stable isotopes and water column structure: Disentangling ecological signals, Mar. Micropaleontol., 101, 127-145, 2013.

Bostock, H. C., Opdyke, B. N., Gagan, M. K., and Fifield, L. K.: Carbon isotope evidence for changes in Antarctic Intermediate Water circulation and ocean ventilation in the southwest Pacific during the last deglaciation, Paleoceanography, 19, PA4013, doi:10.1029/2004PA001047, 2004.

Broecker, W.: Glacial to interglacial changes in ocean chemistry, Prog. Oceanogr., 11, 151-197, 1982.

Broecker, W. S. and Maier-Reimer, E.: The influence of air and sea exchange on the carbon isotope distribution in the sea, Global Biogeochem. Cy., 6, 315-320, 1992.

Bryan, S. P., Marchitto, T. M., and Lehman, S. J.: The release of ${ }^{14} \mathrm{C}$-depleted carbon from the deep ocean during the last deglaciation: Evidence from the Arabian Sea, Earth Planet. Sci. Lett., 298, 244-254, 2010.

Chen, S. X., Li, T. G., Tang, Z., Qiu, X. H., Xiong, Z. F., Nan, Q. Y., Xu, Z. K., and Chang, F. M.: Response of the northwestern Pacific upper water $\delta^{13} \mathrm{C}$ to the last deglacial ventilation of the deep Southern Ocean, Chinese Sci. Bull., 56, 2628-2634, 2011. 
Cléroux, C., deMenocal, P., and Guilderson, T.: Deglacial radiocarbon history of tropical Atlantic thermocline waters: absence of $\mathrm{CO}_{2}$ reservoir purging signal, Quaternary Sci. Rev., 30, 18751882,2011

Curry, W. B. and Oppo, D. W.: Glacial water mass geometry and the distribution of $\delta^{13} \mathrm{C}$ of $\Sigma \mathrm{CO}_{2}$ in the western Atlantic Ocean, Paleoceanography, 20, PA1017, doi:10.1029/2004PA001021, 2005.

Damassa, T. D., Cole, J. E., Barnett, H. R., Ault, T. R., and McClanahan, T. R.: Enhanced multidecadal climate variability in the seventeenth century from coral isotope records in the western Indian Ocean, Paleoceanography, 21, PA2016, doi:10.1029/2005PA001217, 2006.

Dekens, P. S., Lea, D. W., Pak, D. K., and Spero, H. J.: Core top calibration of $\mathrm{Mg} / \mathrm{Ca}$ in tropical foraminifera: Refining paleotemperature estimation, Geochem. Geophys. Geosyst, 3, 1-29, doi:10.1029/2001GC000200, 2002.

De Pol-Holz, R., Keigwin, L., Southon, J., Hebbeln, D., and Mohtadi, M.: No signature of abyssal carbon in intermediate waters off Chile during deglaciation, Nat. Geosci., 3, 192-195, 2010.

De Pol-Holz, R., Mohtadi, M., and Southon, J.: Intermediate water radiocarbon off west Sumatra during the last 45,000 years, EGU General Assembly, Vienna, Austria, 22-27 April 2012, EGU2012-11829, 2012.

Fallet, U., Brummer, G. J. A., Zinke, J., Vogels, S., and Ridderinkhof, H.: Contrasting seasonal fluxes of planktonic foraminifera and impacts on paleothermometry in the Mozambique Channel upstream of the Agulhas Current, Palaeogeography, 25, PA4223, doi:10.1029/2010PA001942, 2010.

Fallet, U., Castañeda, I. S., Henry-Edwards, A., Richter, T. O., Boer, W., Schouten, S., and Brummer, G.-J.: Sedimentation and burial of organic and inorganic temperature proxies in the Mozambique Channel, SW Indian Ocean, Deep Sea Res. Part I, 59, 37-53, 2012

Fine, R. A., Smethie Jr, W. M., Bullister, J. L., Rhein, M., Min, D.-H., Warner, M. J., Poisson, A., and Weiss, R. F.: Decadal ventilation and mixing of Indian Ocean waters, Deep Sea Res. Part I, 55, 20-37, 2008.

Govil, P. and Naidu, P. D.: Evaporation-precipitation changes in the eastern Arabian Sea for the last $68 \mathrm{ka}$, Implications on monsoon variability, Paleoceanography, 25, PA1210, doi:10.1029/2008PA001687, 2010.

Greaves, M., Caillon, N., Rebaubier, H., Bartoli, G., Bohaty, S., Cacho, I., Clarke, L., Cooper, M., Daunt, C., and Delaney, M.: Interlaboratory comparison study of calibration standards for foraminiferal $\mathrm{Mg} / \mathrm{Ca}$ thermometry, Geochem. Geophys. Geosyst., 9, Q08010, doi:10.1029/2008GC001974, 2008.

Hartin, C. A., Fine, R. A., Sloyan, B. M., Talley, L. D., Chereskin, T. K., and Happell, J.: Formation rates of Subantarctic mode water and Antarctic intermediate water within the South Pacific, Deep Sea Res. Part I, 58, 524-534, 2011.

Huguet, C., Kim, J. H., Damsté, J. S. S., and Schouten, S.: Reconstruction of sea surface temperature variations in the Arabian Sea over the last $23 \mathrm{kyr}$ using organic proxies $\left(\mathrm{TEX}_{86}\right.$ and $\left.\mathrm{U}_{37}^{\mathrm{K}^{\prime}}\right), \mathrm{Pa}$ leoceanography, 21, PA3003, doi:10.1029/2005PA001215, 2006.

Hutson, W. H.: Variations in planktonic foraminiferal assemblages along north-south transects in the Indian Ocean, Mar. Micropaleontol., 2, 47-66, 1977.
Ivanochko, T. S., Ganeshram, R. S., Brummer, G.-J. A., Ganssen, G., Jung, S. J., Moreton, S. G., and Kroon, D.: Variations in tropical convection as an amplifier of global climate change at the millennial scale, Earth Planet. Sci. Lett., 235, 302-314, doi:10.1016/j.eps1.2005.04.002, 2005.

Jouzel, J., Masson-Delmotte, V., Cattani, O., Dreyfus, G., Falourd, S., Hoffmann, G., Minster, B., Nouet, J., Barnola, J.-M., and Chappellaz, J.: Orbital and millennial Antarctic climate variability over the past 800,000 years, Science, 317, 793-796, 2007.

Jung, S. J. A., Ganssen, G. M., and Davies, G. R.: Multidecadal Variations in the Early Holocene Outflow of Red Sea Water into the Arabian Sea, Paleoceanography, 16, 658-668, 2001.

Jung, S. J. A., Kroon, D., Ganssen, G., Peeters, F., and Ganeshram, R.: Enhanced Arabian Sea intermediate water flow during glacial North Atlantic cold phases, Earth Planet. Sci. Lett., 280, 220 228, 2009.

Keigwin, L. D.: Radiocarbon and stable isotope constraints on Last Glacial Maximum and Younger Dryas ventilation in the western North Atlantic, Paleoceanography, 19, PA4012, doi:10.1029/2004PA001029, 2004.

Kiefer, T., McCave, I. N., and Elderfield, H.: Antarctic control on tropical Indian Ocean sea surface temperature and hydrography, Geophys. Res. Lett, 33, L24612, doi:10.1029/2006GL027097, 2006.

Lamy, F., Kaiser, J., Ninnemann, U., Hebbeln, D., Arz, H. W., and Stoner, J.: Antarctic timing of surface water changes off Chile and Patagonian ice sheet response, Science, 304, 1959-1962, 2004.

Levi, C., Labeyrie, L., Bassinot, F., Guichard, F., Cortijo, E., Waelbroeck, C., Caillon, N., Duprat, J., de Garidel-Thoron, T., and Elderfield, H.: Low-latitude hydrological cycle and rapid climate changes during the last deglaciation, Geochem. Geophy. Geosy., 8, Q05N12, doi:10.1029/2006GC001514, 2007.

Liu, Z. and Yang, H.: Extratropical control of tropical climate, the atmospheric bridge and oceanic tunnel, Geophys. Res. Lett, 30, 1230, doi:10.1029/2002GL016492, 2003.

Lopes dos Santos, R. A., Wilkins, D., De Deckker, P., and Schouten, S.: Late Quaternary productivity changes from offshore Southeastern Australia: A biomarker approach, Palaeogeogr. Palaeocli. Palaeoecol., 363-364, 48-56, 2012.

Lueckge, A., Deplazes, G., Stuut, J. B., Pätzold, J., Kuhlmann, H., Scheeder, G., and Haug, G.: Monsoonal and oceanographic variability in the Arabian Sea during the last glacial period, AGU Fall Meeting, San Francisco, California, USA, 3-7 December 2012, PP52A-07, 2012.

Lynch-Stieglitz, J., Fairbanks, R. G., and Charles, C. D.: Glacialinterglacial history of Antarctic Intermediate Water: relative strengths of Antarctic versus Indian Ocean sources, Paleoceanography, 9, PA729, doi:10.1029/93PA02446, 1994.

Lynch-Stieglitz, J., Stocker, T. F., Broecker, W. S., and Fairbanks, R. G.: The influence of air-sea exchange on the isotopic composition of oceanic carbon: Observations and modeling, Global Biogeochem. Cy., 9, 653-665, 1995.

Mackensen, A.: On the use of benthic foraminiferal $\delta^{13} \mathrm{C}$ in palaeoceanography: constraints from primary proxy relationships, $\mathrm{Ge}-$ ological Society, London, Special Publications, 303, 121-133, 2008 . 
Mackensen, A.: Strong thermodynamic imprint on Recent bottomwater and epibenthic $\delta^{13} \mathrm{C}$ in the Weddell Sea revealed: Implications for glacial Southern Ocean ventilation, Earth Planet. Sci. Lett., 317-318, 20-26, 2012.

Mangini, A., Godoy, J., Godoy, M., Kowsmann, R., Santos, G., Ruckelshausen, M., Schroeder-Ritzrau, A., and Wacker, L.: Deep sea corals off Brazil verify a poorly ventilated Southern Pacific Ocean during H2, H1 and the Younger Dryas, Earth Planet. Sci. Lett., 293, 269-276, 2010.

Marchitto, T. M., Lehman, S. J., Ortiz, J. D., Flückiger, J., and van Geen, A.: Marine radiocarbon evidence for the mechanism of deglacial atmospheric $\mathrm{CO}_{2}$ rise, Science, 316, 1456-1459, 2007.

Marshall, J. and Speer, K.: Closure of the meridional overturning circulation through Southern Ocean upwelling, Nat. Geosci., 5, 171-180, 2012.

McCartney, M. S.: Subantarctic Mode Water, A Voyage of Discovery: George Deacon 70th Anniversary Volume, Supplement to Deep-Sea Research, edited by: Angel, M. V., Pergamon Press, Oxford, 103-119, 1977.

McClanahan, T. R.: Seasonality in East Africa's coastal waters, Mar. Ecol. Prog. Series, 44, 191-199, 1988.

Mohtadi, M., Lückge, A., Steinke, S., Groeneveld, J., Hebbeln, D., and Westphal, N.: Late Pleistocene surface and thermocline conditions of the eastern tropical Indian Ocean, Quaternary Sci. Rev., 29, 887-896, 2010.

Mook, W., Bommerson, J., and Staverman, W.: Carbon isotope fractionation between dissolved bicarbonate and gaseous carbon dioxide, Earth Planet. Sci. Lett., 22, 169-176, 1974.

Naidu, P. D. and Govil, P.: New evidence on the sequence of deglacial warming in the tropical Indian Ocean, J. Quaternary Sci., 25, 1138-1143, 2010.

Ninnemann, U. S. and Charles, C. D.: Regional differences in Quaternary Subantarctic nutrient cycling: Link to intermediate and deep water ventilation, Paleoceanography, 12, 560-567, 1997.

Oppo, D. W. and Fairbanks, R. G.: Carbon isotope composition of tropical surface water during the past 22,000 years, Paleoceanography, 4, 333-351, 1989.

Pahnke, K. and Zahn, R.: Southern Hemisphere water mass conversion linked with North Atlantic climate variability, Science, 307, 1741-1746, 2005.

Pahnke, K., Goldstein, S. L., and Hemming, S. R.: Abrupt changes in Antarctic Intermediate Water circulation over the past 25,000 years, Nat. Geosci., 1, 870-874, 2008.

Pena, L., Goldstein, S., Hemming, S., Jones, K., Calvo, E., Pelejero, C., and Cacho, I.: Rapid changes in meridional advection of Southern Ocean intermediate waters to the tropical Pacific during the last 30 kyr, Earth Planet. Sci. Lett.s, 368, 20-32, 2013.

Robinson, L. F., Adkins, J. F., Keigwin, L. D., Southon, J., Fernandez, D. P., Wang, S., and Scheirer, D. S.: Radiocarbon variability in the western North Atlantic during the last deglaciation, Science, 310, 1469-1473, 2005.

Rohling, E. J. and Zachariasse, W. J.: Red Sea outflow during the last glacial maximum, Quaternary Int., 31, 77-83, 1996.

Rose, K. A., Sikes, E. L., Guilderson, T. P., Shane, P., Hill, T. M., Zahn, R., and Spero, H. J.: Upper-ocean-to-atmosphere radiocarbon offsets imply fast deglacial carbon dioxide release, Nature, 466, 1093-1097, 2010.
Savoye, B., Ridderinkhof, H., Pätzold, J., and Schneider, R.: Western Indian Ocean Climate and Sedimentation - Cruise No. M75 - 29 December 2007-8 April 2008 - Port Louis (Mauritius) Cape Town (South Africa), METEOR-Berichte, 196, 2013.

Schmitt, J., Schneider, R., Elsig, J., Leuenberger, D., Lourantou, A., Chappellaz, J., Köhler, P., Joos, F., Stocker, T. F., and Leuenberger, M.: Carbon isotope constraints on the deglacial $\mathrm{CO}_{2}$ rise from ice cores, Science, 336, 711-714, 2012.

Schott, F. A. and McCreary Jr., J. P.: The monsoon circulation of the Indian Ocean, Prog. Oceanogr., 51, 1-123, 2001.

Schott, F. A., Dengler, M., and Schoenefeldt, R.: The shallow overturning circulation of the Indian Ocean, Prog. Oceanogr., 53, 57103, 2002.

Schott, F. A., Xie, S.-P., and McCreary Jr., J. P.: Indian Ocean circulation and climate variability, Rev. Geophys., 47, RG1002, doi:10.1029/2007RG000245, 2009.

Sikes, E. L., Samson, C. R., Guilderson, T. P., and Howard, W. R.: Old radiocarbon ages in the southwest Pacific Ocean during the last glacial period and deglaciation, Nature, 405, 555-559, 2000.

Skinner, L., Fallon, S., Waelbroeck, C., Michel, E., and Barker, S.: Ventilation of the deep Southern Ocean and deglacial $\mathrm{CO}_{2}$ rise, Science, 328, 1147-1151, 2010.

Sloyan, B. M. and Rintoul, S. R.: Circulation, Renewal, and Modification of Antarctic Mode and Intermediate Water, J. Phys. Oceanogr., 31, 1005-1030, 2001.

Sortor, R. N. and Lund, D. C.: No evidence for a deglacial intermediate water $\Delta^{14} \mathrm{C}$ anomaly in the SW Atlantic, Earth Planet. Sci. Lett., 310, 65-72, 2011.

Southon, J., Kashgarian, M., Fontugne, M., Metivier, B., and Yim, W. W. S.: Marine Reservoir Corrections for the Indian Ocean and Southeast Asia, Radiocarbon, 44, 167-180, 2002.

Spero, H. J. and Lea, D. W.: The cause of carbon isotope minimum events on glacial terminations, Science, 296, 522-525, 2002.

Stephens, B. B. and Keeling, R. F.: The influence of Antarctic sea ice on glacial-interglacial $\mathrm{CO}_{2}$ variations, Nature, 404, 171-174, 2000.

Stott, L., Southon, J., Timmermann, A., and Koutavas, A.: Radiocarbon age anomaly at intermediate water depth in the $\mathrm{Pa}-$ cific Ocean during the last deglaciation, Paleoceanography, 24, PA2223, doi:10.1029/2008PA001690, 2009.

Stuiver, M., Reimer, P. J., and Reimer, R. W.: CALIB 5.0 (WWW program and documentation), 2005.

Thornalley, D. J. R., Elderfield, H., and McCave, I. N.: Intermediate and deep water paleoceanography of the northern North Atlantic over the past 21000 years, Paleoceanography, 25, PA1211, doi:10.1029/2009PA001833, 2010.

Thornalley, D. J. R., Barker, S., Broecker, W. S., Elderfield, H., and McCave, I. N.: The Deglacial Evolution of North Atlantic Deep Convection, Science, 331, 202-205, 2011.

Visser, K., Thunell, R., and Stott, L.: Magnitude and timing of temperature change in the Indo-Pacific warm pool during deglaciation, Nature, 421, 152-155, 2003.

Weldeab, S., Schneider, R. R., and Kölling, M.: Deglacial sea surface temperature and salinity increase in the western tropical Atlantic in synchrony with high latitude climate instabilities, Earth Planet. Sci. Lett., 241, 699-706, 2006. 
Wyrwoll, K.-H., Dong, B., and Valdes, P.: On the position of southern hemisphere westerlies at the Last Glacial Maximum: an outline of AGCM simulation results and evaluation of their implications, Quaternary Sci. Rev., 19, 881-898, 2000.

You, Y.: Intermediate water circulation and ventilation of the Indian Ocean derived from water-mass contributions, J. Mar. Res., 56, 1029-1067, 1998.

Zahn, R. and Stüber, A.: Suborbital intermediate water variability inferred from paired benthic foraminiferal $\mathrm{Cd} / \mathrm{Ca}$ and $\delta 13 \mathrm{C}$ in the tropical West Atlantic and linking with North Atlantic climates, Earth Planet. Sci. Lett., 200, 191-205, 2002.
Zhang, J., Quay, P., and Wilbur, D.: Carbon isotope fractionation during gas-water exchange and dissolution of $\mathrm{CO}_{2}$, Geochim. Cosmochim. Ac., 59, 107-114, 1995.

Ziegler, M., Diz, P., Hall, I. R., and Zahn, R.: Millennial-scale changes in atmospheric $\mathrm{CO}_{2}$ levels linked to the Southern Ocean carbon isotope gradient and dust flux, Nat. Geosci., 6, 457-461, 2013. 